\title{
IDENTIFIKASI PATAHAN MANADO DENGAN MENGGUNAKAN METODE GEOLISTRIK KONFIGURASI WENNER- SCHLUMBERGER DI KOTA MANADO
}

\author{
Helen Shintia Frans ${ }^{1)}$, As'ari ${ }^{1)}$, Gerald H. Tamuntuan ${ }^{1)}$ \\ ${ }^{1)}$ Program Studi Fisika FMIPA UNSRAT Manado \\ e-mail: hellen_frans@yahoo.co.id; as.ari2222@yahoo.co.id; gtamuntuan@gmail.com
}

\begin{abstract}
ABSTRAK
Peta Geologi lembar Manado Sulawesi Utara, menunjukkan bahwa daerah penelitian Kelurahan Singkil 2 Kecamatan Singkil Kota Manado, merupakan daerah yang dilewati oleh Patahan Manado. Identifikasi patahan dieksplorasi secara geofisika menggunakan metode geolistrik tahanan jenis dengan konfigurasi Wenner- Schlumberger. Akuisisi data menggunakan Multichannel and multielectrode resistivity and IP meter 46 simultaneous channel merek MAE X612-EM. Pengukuran dilakukan pada 3 lintasan pengukuran, dengan jarak antara setiap lintasan satu dengan yang lain adalah 100 meter. Panjang lintasan 1 dan 3 adalah 240 meter sedangkan lintasan 2 adalah 480 meter. Pengolahan data dilakukan dengan menggunakan software RES2DINV yang hasilnya berupa tampang lintang resistivitas bawah permukaan 2 dimensi. Berdasarkan pengolahan dan analisis nilai resistivitas rendah $(\rho<20,9 \Omega \mathrm{m})$ pada lintasan 1,2 , dan 3 yang memotong perlapisan antara batuan yang memiliki nilai resistivitas yang lebih tinggi bidang lemah cenderung terbuka pada bagian permukaan tanah yang diduga sebagai rekahan dengan kedalaman $(3-33,8)$ meter dari permukaan tanah.
\end{abstract}

Kata Kunci : Wenner- Schlumberger, Software RES2DINV, Patahan Manado

\section{MANADO'S FAULT IDENTIFICATION BY USING GEOELECTRIC METHOD WENNER- SCHLUMBERGER CONFIGURATION AT MANADO}

\begin{abstract}
Geology map of Manado, North Sulawesi shows that research region at Singkil 2 Village Subdistrict Singkil is a track of Manado's Fault. Identification of this fault use geoelectric geophysics resistivity method with Wenner- Schlumberger. Multichannel and multielectrode resistivity and IP meter 46 simultaneous channels MAE brand X612- EM is device for acquisition of data. The measurements were taken at three tracks to the distance between each track one another is 100 meters. The length of first track and third track is 240 meters, and second track is 480 meters. The data Processing was performed with RES2DINV software that results 2D image subsurface resistivity. Based on the data processing and analyses of low resistivity values $(\rho<20.9 \Omega \mathrm{m})$ on the track 1, 2 and 3 are cut layers of rock that have higher resistivity values to from fractures tend to open on the ground of suspected fracture at a depth is 3 meters to 33,8 meters from the surface.
\end{abstract}

Keywords : Wenner- Schlumberger, RES2DINV, Manado Fault.

\section{PENDAHULUAN}

Secara geologis Sulawesi Utara terletak pada daerah pertemuan Lempeng Eurasia, Lempeng Pasifik, Lempeng IndoAustralia dan Lempeng Philipina sehingga merupakan salah satu daerah yang rawan bencana gempabumi. Oleh sebab itu sudah tentu kondisi ini menimbulkan sejumlah patahan yang suatu saat dapat menimbulkan gempabumi.

Patahan - patahan yang ada di Sulawesi Utara antara lain Patahan Manado, dan Patahan Amurang. Berdasarkan Peta geologi Lembar Manado, Sulawesi Utara (Effendi dan Bawono, 1997 dalam Poedjopratjino, 2009) didaerah Sulawesi Utara terdapat Patahan Manado yang teridentifikasi secara geologi akan tetapi 
hingga saat ini belum pernah dilakukan survei geofisika bawah permukaan untuk mengetahui lokasi atau posisi tepat Patahan Manado tersebut.

Penelitian sebelumnya telah dilakukan oleh Manuho, dkk (2015) di Jalan Ringroad, Kelurahan Malendeng, Kecamatan Paal II dengan menggunakan konfigurasi Half Schlumberger untuk mengidentifikasi Patahan Manado. Berdasarkan Peta Geologi Lembar Manado, Patahan Manado melintasi daerah Ringroad dan Singkil. Hal ini mendorong penulis untuk melakukan penelitian di tempat yang lain dengan kondisi geologi yang sama, yaitu pada daerah Kelurahan Singkil 2, Kecamatan Singkil Manado.

Metode yang digunakan dalam penelitian ini adalah metode geolistrik tahanan jenis konfigurasi WennerSchlumberger. Metode geolistrik tahanan jenis konfigurasi Wenner ini diharapkan mampu memberikan informasi tentang resisitivitas batuan dan kondisi struktur bagian bawah permukaan di daerah penelitan Kelurahan Singkil 2, Kecamatan Singkil.

\section{Rumusan masalah}

Identifikasi keberadaan Patahan Manado dengan menggunakan Metode Geolistrik Resistivitas.

\section{Batasan masalah}

Penelitian ini dibatasi pada letak geografis di Kelurahan Singkil 2, Kecamatan Singkil kota Manado, menggunakan metode geolistrik tahanan jenis konfigurasi WennerSchlumberger.

\section{Tujuan penelitian}

Penelitian ini bertujuan untuk mengidentifikasi Patahan Manado dengan menggunakan metode geolistrik tahanan jenis konfigurasi Wenner- Schlumberger di wilayah Kelurahan Singkil 2, Kecamatan Singkil Manado.

\section{Manfaat penelitian}

Berdasarkan tujuan penelitian diatas, maka penelitian ini diharapkan berguna untuk memberikan informasi bagi pemerintah dan masyarakat setempat mengenai struktur bawah permukaan dangkal yang berpotensi menimbulkan bencana gempa bumi.
Rekahan terjadi pada saat gejala tektonik yang terjadi pada permukaan bumi mengakibatkan adanya deformasi, deformasi batuan adalah suatu proses penghancuran suatu batuan yang bersifat plastis menjadi batuan lebih kecil, dan mengakibatkan batuan yang bersifat ductile menjadi retak dan terbentuk rekahan - rekahan di seluruh permukaan batuan. Rekahan mengakibatkan batuan menjadi bagian- bagian terpisah, maka struktur rekahan atau rongga batuan menjadi jalan yang dilalui cairan dari luar beserta materi lain seperti air, gas dan unsur - unsur lain yang serupa.

Patahan adalah suatu rekahan pada batuan di permukaan bumi dimana bagian yang dipisahkan oleh rekahan itu bergerak satu terhadap lainnya. Pada patahan terdapat dua bagian yang harus dipahami yaitu footwall serta hangingwall. Footwall adalah bagian yang terletak di bawah bidang sesar, sedangkan bagian yang di atas patahan disebut hangingwall.

\section{Metode Geolistrik Tahanan Jenis Konfigurasi Wenner- Schlumberger}

Metode geolistrik tahanan jenis (resistivitas) adalah salah satu dari kelompok metode geofisika yaitu suatu metode untuk mempelajari keadaan bawah permukaan bumi dengan cara mempelajari sifat aliran listrik di dalam batuan di bawah permukaan bumi berdasarkan perbedaan resistivitas batuan. Prinsip kerja dari metode geolistrik resistivitas adalah mengalirkan arus listrik melalui dua elektroda arus, kemudian beda potensialnya diukur melalui dua elektroda potensial, sehingga nilai resistivitasnya dapat dihitung. Tahanan jenis (resistivitas) merupakan suatu besaran yang menunjukkan tingkat hambatan terhadap arus listrik dari suatu bahan (Adriyani, dkk 2010).

\section{Sifat Kelistrikan Batuan}

Sifat kelistrikan batuan adalah karakteristik batuan bila dialirkan arus listrik ke batuan tersebut. Arus listrik ini dapat berasal dari alam itu sendiri atau arus listrik yang sengaja diinjeksikan ke batuan tersebut. Aliran arus listrik pada batuan dapat digolongkan menjadi tiga macam, yaitu konduksi secara elektronik, konduksi secara elektrolitik, dan konduksi secara dielektrik (Telford dan Sherif.,1990). 


\section{Konduksi secara elektronik}

Semakin besar nilai resistivitas suatu bahan maka semakin sulit bahan tersebut menghantar arus listrik, begitu pula sebaliknya. Resistivitas memiliki pengertian yang berbeda dengan resistansi (hambatan), dimana resistansi tidak hanya bergantung pada bahan tetapi juga bergantung pada faktor geometri atau bentuk bahan tersebut, sedangkan resistivitas tidak bergantung pada faktor geometri. Jika ditinjau suatu silender dengan panjang $\mathrm{L}$, luas penampang $\mathrm{A}$, resistivitas $\rho$ dan resistansi.

$$
R=\rho \frac{L}{A}
$$

Jika panjang konduktor berbentuk silender (L) dinaikkan, maka resistansi akan meningkat, dan apabila diameter silender konduktor diturunkan yang berarti luas penampang (A) berkurang maka resistansi juga meningkat. Rho $(\rho)$ adalah resistivitas (tahanan jenis) dalam $\Omega \mathrm{m}$. Sedangkan menurut hukum Ohm, resistansi $R$ dirumuskan :

$$
R=\frac{V}{I}
$$

Sehingga didapatkan nilai resistivitas $(\rho)$

$$
\rho=\frac{V A}{I L}
$$

Konduktivitas $(\sigma)$ batuan merupakan kebalikan dari resistivitas $(\rho)$ dengan satuan $\Omega \mathrm{m}$, maka

$$
\begin{gathered}
\sigma=\frac{1}{\rho}=\frac{I L}{V A}=\left(\frac{I}{A}\right)\left(\frac{L}{V}\right)=\frac{\vec{J}}{\vec{E}} \ldots \ldots . .(4) \\
\text { Dimana } \quad \vec{J} \text { adalah rapat arus }
\end{gathered}
$$
(ampere/meter ${ }^{2}$ ) dan $\vec{E}$ adalah medan listrik (volt/meter).

Untuk medium yang tidak homogen tahanan jenis yang terukur adalah tahanan jenis semu (apparent resistivity). Nilai tahanan jenis semu tergantung pada tahanan jenis lapisan-lapisan pembentuk formasi dan konfigurasi elektroda yang digunakan. Pendekatan sederhana untuk memperoleh tahanan jenis batuan dalam bumi yaitu dengan mengasumsikan bahwa bumi merupakan suatu material homogen isotropis. Jika arus listrik dengan rapat arus $\vec{J}$ dialirkan ke dalam bumi, maka arus tersebut akan menyebar ke segala arah secara merata
(As'ari,2009). Aliran arus yang melalui suatu elemen luasan $A$ dituliskan sebagai :

$$
I=\vec{J} A
$$

Rapat arus $\vec{J}$ dan medan listrik $\vec{E}$ dihubungkan dalam hokum Ohm, yaitu :

$$
\vec{J}=\frac{I}{\rho} \vec{E}
$$

\section{Konduksi secara elektrolitik}

Konduksi secara elektrolitik terjadi jika batuan bersifat porus dan pori-pori tersebut terisi fluida-fluida elektrolitik. Pada kondisi ini aliran arus listrik dibawa oleh ion-ion elektrolit. Konduktivitas akan semakin besar jika kandungan air dalam batuan bertambah banyak, dan sebaliknya resistivitas akan semakin besar jika kandungan air dalam batuan berkurang.Hal ini dikarenakan sebagian besar batuan merupakan konduktor yang buruk dan memiliki resistivitas yang sangat tinggi.

\section{Konduksi secara dielektrik}

Konduksi secara dielektrik terjadi jika batuan bersifat dielektrik artinya batuan tersebut mempunyai elektron bebas sedikit bahkan tidak memiliki elektron bebas. Peristiwa pada kondisi ini berbeda, tergantung konstanta dielektrik yang dimiliki batuan.

Medan listrik dari luar mempengaruhi elektron dalam bahan sehingga berpindah dan berkumpul terpisah dari inti, maka terjadi polarisasi. Konduktivitas listrik $(\sigma)$ berkaitan dengan porositas batuan dan mobilitas dari air atau fluida lainnya yang melewati ruang berpori. Konduktivitas tergantung pada sifat mobilitas ionik dan konsentrasi larutan, viskositas, temperatur, dan tekanan.

\section{Sumber arus tunggal dipermukaan}

Untuk permukaan setengah bola arus yang mengalir memenuhi persamaan 7 :

$$
I=-2 \pi \sigma A
$$

Maka $A=-\frac{I \rho}{2 \pi}$ dengan $\rho=\frac{1}{\sigma}$

Sehingga diperoleh

$$
V=-\frac{A}{r}=\left(\frac{I \rho}{2 \pi}\right) \frac{1}{r} \text { atau } \rho=2 \pi r \frac{V}{I} \ldots
$$

Permukaan equipotensial adalah permukaan setengah bola dengan garis aliran arus lurus dan medan listriknya berupa 
lingkaran yang berarah radial, seperti terlihat pada (Gambar 1).

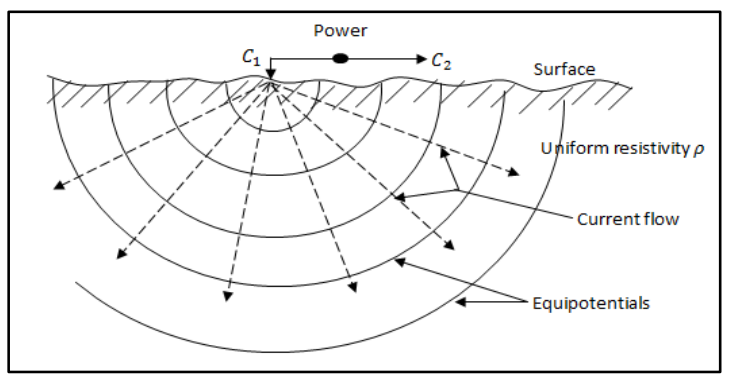

Gambar 1 Pola arus listrik arus tunggal.

\section{Dua sumber arus di permukaan}

Jika jarak antara kedua elektroda terbatas (Gambar 2). Potensial listrik pada titik- titik yang berdekatan akan dipengaruhi oleh kedua elektroda arus tersebut.

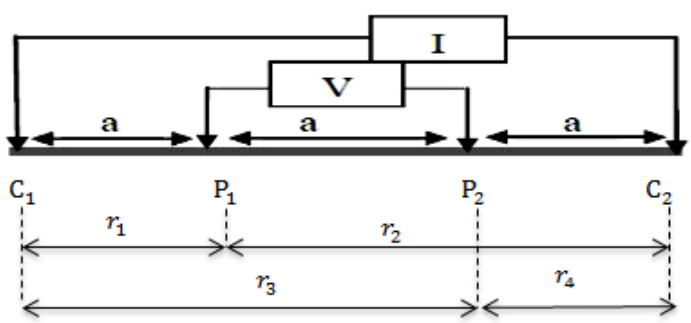

Gambar 2 Dua sumber arus di permukaan

Sehingga potensial yang disebabkan oleh $C_{1}$ dan $\mathrm{P}_{1}$ adalah :

$V_{1}=-\frac{A_{1}}{r_{1}} \operatorname{dimana} A_{1}=-\frac{I \rho}{2 \pi}$

Demikian juga potensial yang disebabkan $\mathrm{C}_{2}$ dan $\mathrm{P}_{1}$ adalah :

$V_{2}=\frac{A_{2}}{r_{2}} \operatorname{dimana} A_{2}=\frac{I \rho}{2 \pi}$

Sehingga potensial pada titik $\mathrm{P}_{1}$ adalah :

$V_{1}+V_{2}=\frac{I \rho}{2 \pi}\left(\frac{1}{r_{1}}-\frac{1}{r_{2}}\right)$

Cara yang sama digunakan untuk menentukan potensial di titik $\mathrm{P}_{2}$. Sehingga diperoleh beda potensial antara $\mathrm{P}_{1}$ dan $\mathrm{P}_{2}$ dengan $\rho=\rho_{a}$ adalah :

$\Delta V=\frac{I \rho_{a}}{2 \pi}\left\{\left(\frac{1}{r_{1}}-\frac{1}{r_{2}}\right)-\left(\frac{1}{r_{3}}-\frac{1}{r_{4}}\right)\right\}$ atau

$\Delta V=\frac{I \rho}{2 \pi} K$
Besaran $2 \pi\left[\frac{1}{r_{1}}-\frac{1}{r_{2}}-\frac{1}{r_{3}}+\frac{1}{r_{4}}\right]^{-1}$ merupakan faktor geometri konfigurasi elektroda $(K)$, yang tergantung pada susunan elektroda. Harga $\mathrm{K}$ ini dapat dihitung apabila jarak antara elektroda satu dengan yang lainnya diketahui, selanjutnya dapat ditentukan dengan pembacaan $\frac{\Delta V}{I}$ dan nilai apparent resistivity dapat diperoleh dengan persamaan:

$$
\rho=2 \pi \frac{\Delta V}{K I}
$$

\section{Konfigurasi Wenner - Schlumberger}

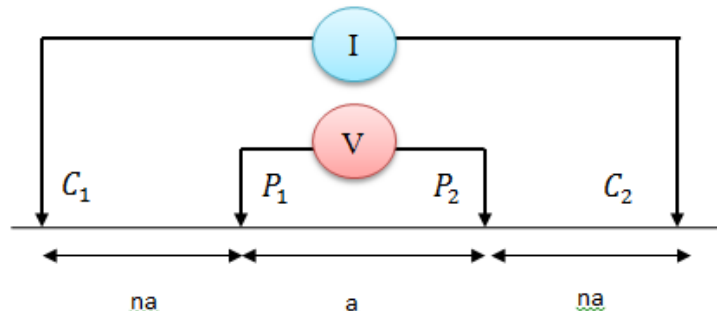

Gambar 3 Susunan Elektroda WennerSchlumberger.

Faktor Geometri Wenner Schlumberger :

$$
K=\pi n(n+1) a \text {. }
$$

sehingga nilai resistivitas semu untuk konfigurasi Wenner- Schlumberger :

$$
\rho_{a}=\pi n(n+1) a\left(\frac{\Delta V}{I}\right)
$$

\section{METODE PENELITIAN}

\section{Desain Survei}

Pada penelitian ini, pengukuran dilakukan pada 3 lintasan dengan jarak antara setiap lintasan 100 meter. Panjang lintasan 1 dan 3 adalah 240 meter sedangkan lintasan 2 adalah 480 meter. Dengan menggunakan 48 buah elektroda setiap lintasan, dan jarak spasi pengukuran pada lintasan 1 dan 3 adalah 5 meter sedangkan pada lintasan 2 jarak masing- masing titik pengukuran adalah 10 meter. 


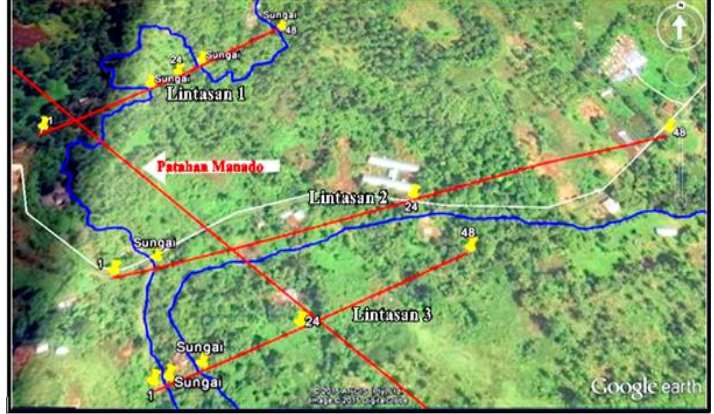

Gambar 4 Desain Survei lokasi penelitian

Terlihat jelas bahwa pada lintasan 1 memotong garis Patahan Manado pada elektroda ke (3-4), untuk lintasan 2 garis Patahan Manado berada pada elektroda ke (16), dan lintasan 3 garis Patahan Manado pada elektroda ke (24). Lintasan 1 dilalui 3 aliran sungai, lintasan 2 dilalui 1 aliran sungai dan lintasan 3 dilalui juga 2 aliran sungai. Lokasi penelitian diambil dari peta Google Earth.

\section{Lokasi dan Waktu}

Survei Geolistrik dilaksanakan di Kelurahan Singkil 2, Kecamatan Singkil Kota Manado pada (1³0'34.63"-1³0'21.65") LU; (12451'23.58'- 124'51'42.93') BT dengan menggunakan konfigurasi WennerSchlumberger yang berlangsung dari bulan Maret - Mei 2015. Pengolahan data dilaksanakan di Laboratorium Geofisika Jurusan Fisika FMIPA UNSRAT.

\section{Alat dan Bahan}

Alat yang digunakan dalam penelitian ini adalah sebagai berikut :

Multichannel and multielectrode resistivity X612 EM, GPS perangkat utama, Google Earth, Software Surfer 8, Software RES2DINV, Peta Geologi.

\section{HASIL DAN PEMBAHASAN}

\section{Hasil Analisis Jalur Patahan Manado Pada Lokasi Penelitian}

Berdasarkan hasil pengolahan data dari ketiga lintasan konfigurasi WennerSchlumberger diperoleh model tampang lintang resistivitas pada setiap lintasan. Pada lintasan 1 seperti terlihat pada (Gambar 6) memiliki nilai resitivitas rendah $(\rho<$ $20,9 \Omega \mathrm{m}$ ) pada meter ke (10-75) dari pusat bentangan dengan kedalaman sekitar 6,3828,7 meter dari permukaan tanah pada bidang lemah ini diduga sebagai rekahan, karena rekahan adalah massa batuan yang telah memperlihatkan gejala pergeseran pada kedua sisi bidang rekahan. Rekahan cenderung terbuka dibagian permukaan tanah yang tidak beraturan. Dilihat dari kondisi pengambilan data dilokasi penelitian sebelum elektroda 1 pada lintasan 1 ini terdapat tebing dan sungai yang merupakan faktor adanya indikasi patahan.

Berdasarkan (Gambar 7) lintasan 2, menunjukkan bidang lemah yang mempunyai nilai resistivitas rendah $(\rho<20,9 \Omega \mathrm{m})$. Bentuk rekahan yang cenderung terbuka pada bagian permukaan tanah yang memotong perlapisan antara batuan yang memiliki nilai resistivitas yang lebih tinggi dan terdapat pada meter ke (170-200) dari elektroda 1. Pada kedalaman berkisar (3-25) meter dari permukaan tanah diduga sebagai rekahan.

Berdasarkan Gambar (8), hasil tampang lintang lintasan 3 yang dapat diamati mempunyai nilai resistivitas rendah $(\rho<20,9 \Omega \mathrm{m})$. Pada meter ke $\quad(85-115)$ dari pusat bentangan dengan kedalaman sekitar 6,38-33,8 meter dari permukaan tanah. Hal tersebut diduga sebagai rekahan yang tertimbun oleh materi batuan yang resistivitasnya lebih besar.

Oleh karena itu, ketiga lintasan ini dapat memberikan informasi tentang keberadaan struktur bawah permukaan dangkal, dengan adanya tanda- tanda patahan Manado seperti rekahan. Setelah dilakukan pengukuran menggunakan metode geolistrik konfigurasi Wenner- Schlumberger secara geofisika, dengan melihat garis patahan manado pada Peta Geologi. Hasilnya hampir bersesuaian pada ketiga lintasan penelitian ini yang diduga sebagai rekahan. Sehingga pemerintah dan warga setempat dapat melakukan mitigasi gempa bumi secara dini. 


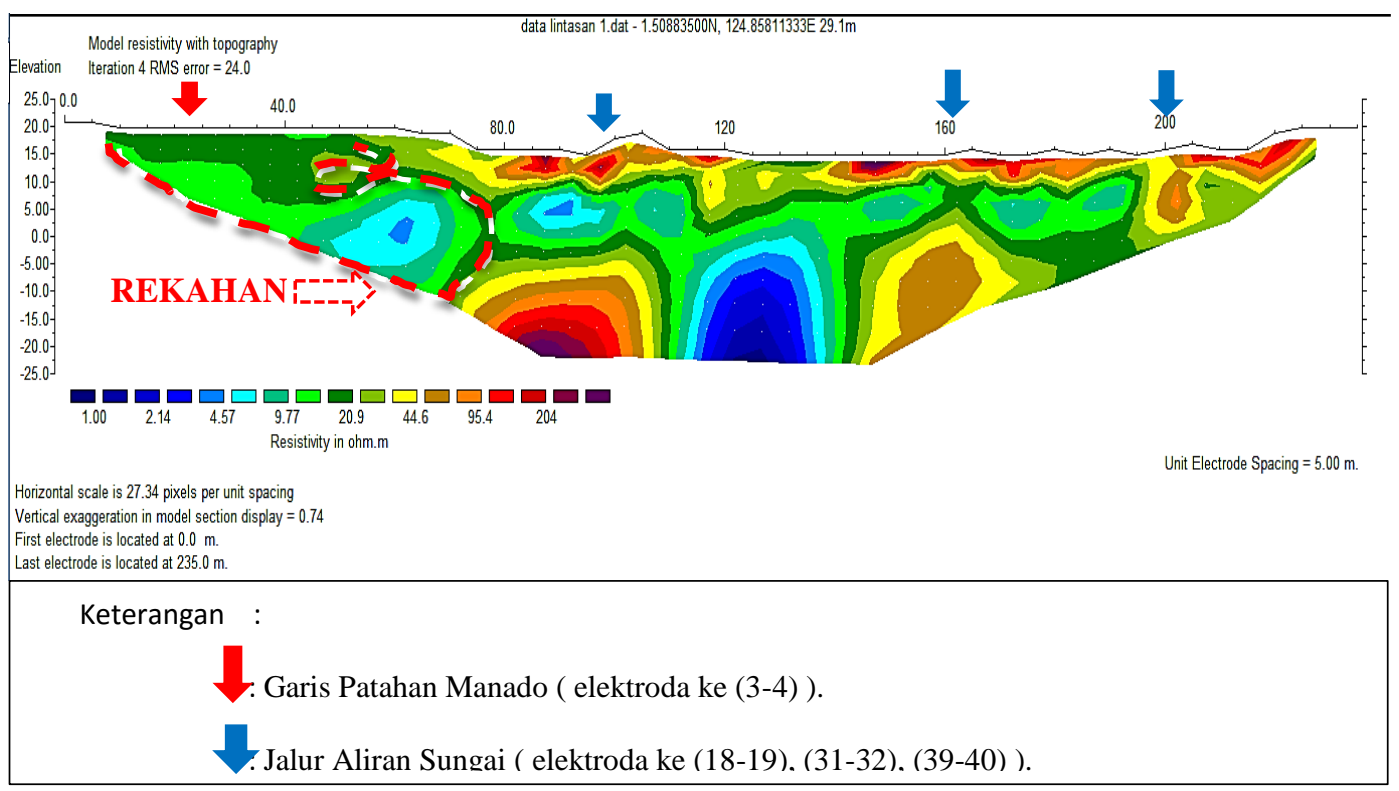

Gambar 6 Model Tampang Lintang Resistivitas 2D Konfigurasi Wenner- Schlumberger

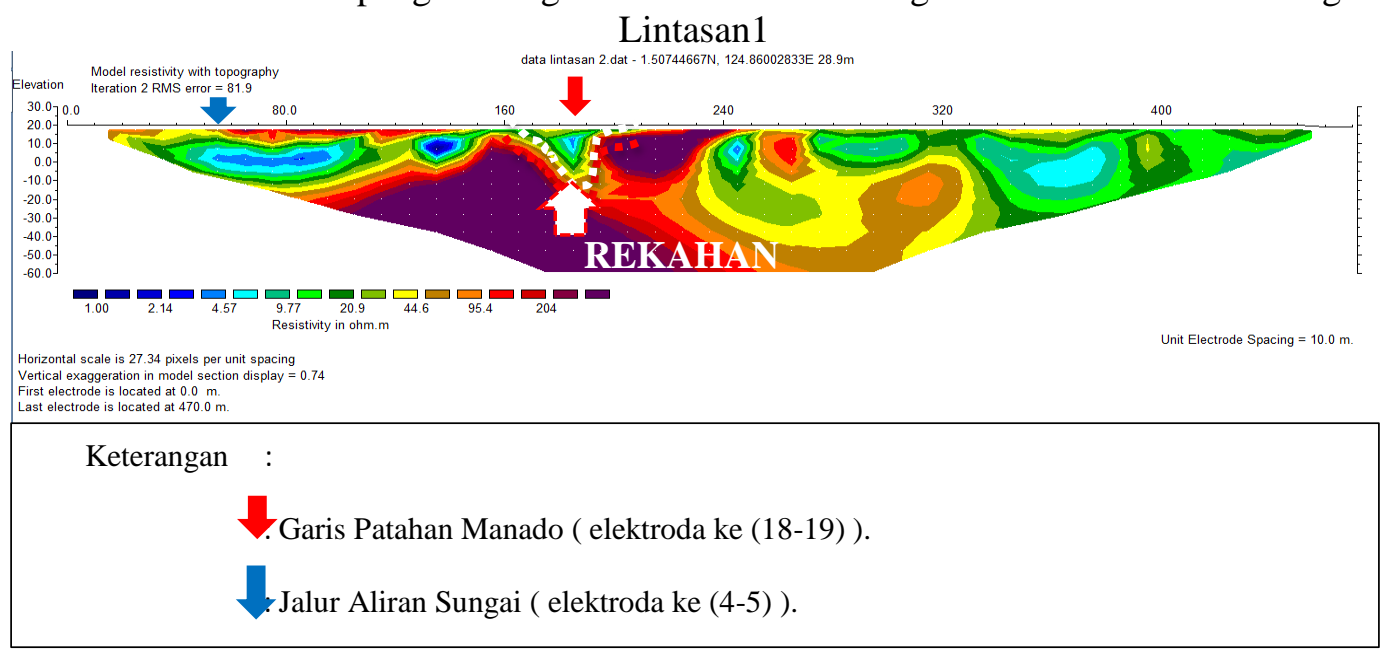

Gambar 7 Model Tampang Lintang Resistivitas 2D Konfigurasi Wenner- Schlumberger Lintasan2

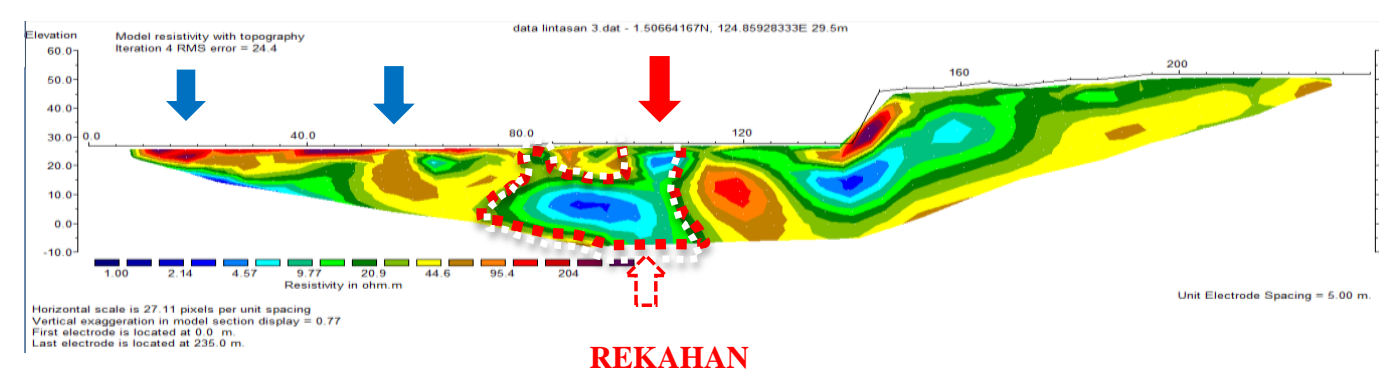

REKAHAN

Keterangan :

: Garis Patahan Manado ( elektroda ke (20-22))

: Jalur Aliran Sungai ( elektroda ke (2-3), (11-12)).

Gambar 8 Model Tampang Lintang Resistivitas 2D Konfigurasi Wenner- Schlumberger Lintasan3 


\section{KESIMPULAN DAN SARAN}

\section{Kesimpulan}

1). Identifikasi Patahan Manado dengan menggunakan metode geolistrik resistivitas konfigurasi Wenner- Schlumberger, di Kelurahan Singkil 2 Kecamatan Singkil Manado. Diperoleh bidang lemah dengan resistivitas rendah $(\rho<20,9 \Omega \mathrm{m})$ pada lintasan 1, 2, dan 3 yang memotong perlapisan antara batuan yang memiliki nilai resistivitas yang lebih tinggi.

2). Bidang lemah berbentuk terbuka ke atas, tidak teratur dan diduga sebagai rekahan. Rekahan terletak pada jalur Patahan Manado,mempunyai kedalaman $\quad 3-33,8$ meter dari permukaan tanah.

\section{Saran}

Untuk mendapatkan hasil yang lebih baik, maka penulis menyarankan : Perlu dilakukan penelitian yang berkelanjutan dengan metode dan konfigurasi yang sama, dengan menambahkan lintasan pengukuran.

\section{DAFTAR PUSTAKA}

Andriyani, Satuti., Ramelan, A.H, and Sutarno. 2010. Metode Geolistrik Imaging Konfigurasi Dipole - dipole Digunakan untuk Penelusuran Sistem Sungai Bawah Tanah pada Kawasan Karst di Pacita Jawa Timur. Jurnal EKOSAINS, 2(1): 46-54.

As'ari. 2009. Pemetaan Paleo- Morphology Abad VIII Di Kompleks Candi Prambanan Dengan Menggunakan Metode Geolistrik [Tesis]. FMIPA UGM. Yogyakarta.

Effendi,A.C., dan S.S. Bawono. 1997. Peta Geologi Lembar Manado, Sulawesi utara, Edisi ke - 2 pusat penelitian dan pengembangan Geologi,Bandung.

Manuho, J. 2015. Identifikasi patahan manado dengan menggunakan metode geolistrik konfigurasi Half Schlumberger di kota Manado [skripsi]. FMIPA Universitas Sam Ratulangi, Manado.

Telford, W., dan Sheriff. 1990. Applied Gheophysics. Cambridge : Cambridge University Press, London 